\title{
Enforcement Intensity in Danish Drug Control, 1996-2017
}

\author{
Kim Moeller ${ }^{1}$ \\ Published online: 15 February 2020 \\ (C) The Author(s) 2020
}

\begin{abstract}
Enforcement intensity towards drug law offences in Denmark has increased since 2004, making Denmark one of the few Western countries that is heading towards a more repressive drug control approach. The aim of this study is to examine patterns and correlates of drug enforcement intensity over time. Policy documents and criminal statistics on drug law offences, from 1996 to 2017, are analysed in the context of the rationality perspective and the theory of policy coherence. Time series analyses and bivariate tests of statistical significance are used to examine enforcement intensity over time, between seasons, and in the gender and ethnic composition of convictions. Three periods are identified, delineated by documents that set forth drug policy aims. From 1996 to 2003, a series of qualitative changes to the legal framework was introduced, followed by a quantitative increase in enforcement pressure from 2004 to 2010 with a focus on Copenhagen. From 2011 to 2017, other regions of the country also increased enforcement. The increased intensity in drug control followed a period of increasing cannabis prevalence rates. The increase in reported minor drug law offences correlated with increased seasonal variations and increased disparity in the gender and ethnicity of convicted individuals.
\end{abstract}

Keywords Drug policy · Deterrence · Denmark · Policy implementation · Policy coherence

\section{Introduction}

The market for illicit drugs is arguably the largest of all the illegal markets, and criminal justice policies to suppress it take up a substantial part of police resources. Yet, the interaction between law enforcement and these markets is poorly understood (Bushway and Reuter 2008). An important aspect of this problem is the lack of comparable data and comparative analysis (Burris 2017; Ødegård 1998). Researching drug policies and their implementation is

Kim Moeller

kim.moeller@mau.se

1 Malmö University, Jan Waldenströms gata 25, 21428 Malmö, Sweden 
relevant as they change rapidly. Internationally, several US states, Canada, and Uruguay have legalised cannabis and many European countries have implemented or are considering "decriminalisation" as an option (Rogeberg 2018). Denmark is one of the few Western countries that is going in the opposite direction, away from a lenient decriminalised policy and towards a more repressive approach.

Starting in the late 1960s, Danish policymakers decided on exceptions on the stringent controls set out in the UN conventions (Bruun and Rosenqvist 1980; Laursen and Jepsen 2002). This policy was motivated in the trade-off between competing goals, conceptualised as a choice between use reduction and harm reduction (Caulkins and Reuter 1997). Prioritizing harm reduction implied keeping the markets for cannabis and other drugs separate and avoiding criminal sanctions where drug use was the primary offence (Pedersen and Skardhamar 2010). The mid-1990s saw a change towards a focus on use reduction and a series of legal amendments increased criminal sanctions for drug-related offences (Balvig 2005; Houborg 2010). This course continued into the 2000s with a crackdown on a large openair cannabis market (Moeller 2018a), and a change in practice towards issuing fines for possession offences, instead of formal warnings (Houborg et al. 2016).

This oscillation between policy goals is a historical feature of Danish drug control that tends to move in phases of 5 to 9 years. Laursen and Jepsen (2002) found a series of "break periods" with a focus on qualitative adjustments to the legal framework, followed by "transition periods" with quantitative changes in enforcement intensity. Adam and Raschzok (2014) noted that policies towards addictive behaviours tend to change when the underlying "problem pressure" makes current policy appear incoherent. Policymakers seek to re-establish coherence and legitimacy by adjusting the legal framework or law enforcement efforts to external pressures or changes in addictive behaviours.

Drug control policies primarily consist of legislation and law enforcement aimed at reducing drug availability (MacCoun and Reuter 2001). These policies build on deterrence and rationality perspectives where the size of drug markets should be reduced as penalties are increased, become more certain, and are enforced more quickly (Bushway and Reuter 2008; Cornish and Clarke 1986; May and Hough 2001). The existing research, however, has focused on legislation and penalties, neglecting the enforcement component (Burris 2017; Ritter et al. 2016; Ødegård 1998). This is noteworthy when considering the insight from deterrence research that the certainty of criminal sanctioning has a stronger effect than the eventual severity of the sanction (Nagin and Paternoster 1991). For drug control policies, this implies the enforcement intensity is arguably more important than the size of fines and maximum penalty levels (Nguyen and Reuter 2012). Further, enforcement is the heaviest cost component, constituting upwards of $76 \%$ of public drug expenditure (in Sweden and the Netherlands) (Reuter 2006).

Policing can influence the availability of illicit drugs; however, there are only a few studies that compare how policies have been implemented over time (Ritter et al. 2016). Studies on national policies is an important first step in establishing a better understanding of European drug law enforcement and evaluating the potential outcomes of various policy options. This study is aimed at describing patterns and correlates of regarding enforcement intensity towards drugs in Denmark. The analysis pertains to discussions about the oscillating priorities in control policy and the consequences of implementing low-level drug law enforcement. I apply a routine activity perspective to examine patterns in reported offences and criminal sanctions (Cohen and Felson 1979). Here, variations in criminal sanctioning for drug offences are understood as a reflection of opportunities for control. To assess change in opportunities for 
control, I depart from a description of drug prevalence rates and a content analysis of policy documents and drug law amendments. These documents constitute the formal interpretation of the problem pressure derived from illicit drug use in Denmark. Next, I examine how drug control intensity has developed over time in comparison with the trend in overall offending. I further examine if the overall trend hides regional and seasonal variations. Conceivably, a large crackdown in one region of the country, e.g. Christiania in Copenhagen, for a limited time (Moeller 2010), may affect overall rates.

For lower level drug offences, police-initiated contact is the norm and individual-level characteristics may influence the probability of criminal sanctions (Houborg et al. 2016; Medina 2014). Lower level offences display disparity for gender (e.g. Moeller 2012; Nguyen and Reuter 2012) and ethnicity (e.g. Golub et al. 2007; Harcourt and Ludwig 2007), with men and ethnic minorities overrepresented. Some researchers see it as part of a broader culture of control (Mooney and Young 2006) while others note a more ad hoc process of target selection (Weisburd and Green 1995). In the opportunity perspective, some segments of drug users are more likely to be controlled by police because they are less discrete in their purchasing modes, more prone to use in public, or have a higher use frequency (Nguyen and Reuter 2012). Extending this reasoning, we also know that drug prevalence rates are higher in larger cities (Babor et al. 2010), and that crime rates are affected by seasonal variations in temperature (Ratcliffe 2006). This speaks to the motivations for changing drug control policy. I assess if the gender and ethnic composition of criminal sanctions change with varying levels of enforcement intensity and discuss the findings in relation to the theoretical predictions from the opportunity perspective and prior research on changing drug policy priorities. The focus is on the period from 1996 to 2017, which marks the beginning of the last break period analysed by Laursen and Jepsen (2002) and the last year from which data is available.

\section{Data and Methods}

Drawing data from the National Board of Health, I estimate Danish drug prevalence rates over time. This forms the basis of the hypothesis that the underlying problem pressure may spur changes in policy and enforcement intensity. The focus is on cannabis as it is the most widely used illicit drug (Babor et al. 2010). Other drug types, such as cocaine and heroin, cause more problem pressure per user, but as their use is less widespread, they provide fewer opportunities for control. The monetary value of the cannabis market is also an important component of drug-related problem pressure.

The contents of policy documents and legal amendments form the hypothesised pivotal years between break and transition periods. Specifically, the documents consist of a white paper (Ministry of Justice, Social Ministry, and Health Ministry 1994) and two action plans, entitled The Fight against Drugs I and II (Government 2003, 2010) and four legal amendments that followed.

To measure enforcement intensity, I rely on the national statistics bureau, Denmark's Statistics. Offences fall into two categories, penal law and special laws, which broadly correspond with the distinction between felonies and misdemeanours. The special laws category is dominated by traffic offences and shoplifting, but also covers the Law on Euphoria-Inducing Substances (LES). LES offences are drug law misdemeanours, mostly possession for personal use and small-scale selling. The large-scale sale, manufacturing, and trafficking of drugs is contained in Section 191 of the penal code. The amounts that delineate 
these categories vary by type of drug: $10 \mathrm{~kg}$ for cannabis, $25 \mathrm{~g}$ for heroin, $25 \mathrm{~g}$ for cocaine, and $50 \mathrm{~g}$ for amphetamine (Attorney General 2006). Denmark, like most European countries, does not register drug offences by the type of drug involved (Mounteney et al. 2016) but police data suggest that most seizures are for cannabis. Since 2000, approximately 60\% (range 55-71\%) of all seizures have been of cannabis while 14\% (range 10-17\%) have been of cocaine (EMCDDA webpage).

For the research questions on national trend, as well as regional and seasonal variations, I use reported offences, which contains incidents where drugs were found and police completed the investigation. The advantage of reported offences is that a proportion of reported offences do not result in convictions, and reported offences are, therefore, a better reflection of policy implementation compared with convictions (Pedersen and Skardhamar 2010). For the analysis, I examine differences with nonparametric bivariate statistical analysis. I use $t$ tests to assess the statistical significance of the difference in mean annual numbers of offences between periods. To further explore the trend, I also compare the number of offences in each of the three periods against a hypothesised even distribution using chi-squared tests.

Next, I examine the geographic distribution and seasonal variations in drug law offences in a time series analysis. The analysis of the geographic distribution of offences uses data collected in police districts that are only available for 2007-2017. The seven biggest police districts have $80 \%$ of all reported LES offences while the remaining five districts have a low population density and only a few reported offences. I report average enforcement intensity relative to population size for each police district and calculate linear trend lines with year as the regressor variable. This gives a simple indicator of the temporal trend that can then be compared across districts.

Next, I examine seasonal variations as a way to probe the question of police opportunity and proactivity. From the opportunity perspective, more people on the streets during warm months imply more opportunities to issue fines (Cohen and Felson 1979; Ratcliffe 2006). I examine if the number of reported drug law offences vary by quarter and by season over the period 1996-2017. I use an autoregressive integrated moving average (ARIMA) complex linear model to test if variations in the time series are attributable to white noise processes for the residuals or reflect a pattern. I specify a model based on best fit and use the Ljung-Box statistic to test the null hypothesis that variations between quarters are random (Box and Jenkins 1970). A significant test suggests the variation is not white noise but reflects a pattern. To substantiate the findings, I also test if there are systematic quarterly variations in overall misdemeanour offences. The output, seasonal adjustment factors, indicates if the effect of each quarter on the level of the total series is positive or negative. Lastly, I examine variations between summer months and winter months, operationalised as the first and fourth quarter of the year, with the number during summer months in the second and third quarter of the year. The proposed break and transition periods delineate the groups in the analysis and the output measures if there is an association between enforcement intensity and level of seasonal variations.

Lastly, I use data on convictions to test for disparities in gender and ethnicity. Prior research suggests that proactive policing of drug offences increases the share of males and ethnic minorities (Golub et al. 2007; Moeller 2012). Here, I examine if changes in enforcement intensity have led to changes in the composition of sanctioned individuals. Conviction data contains details on sanctioned individuals, but the data on ethnic origin only began in 2000 and was bi-annual until 2005. The categories "non-Western immigrants," and "descendants of nonWestern immigrants," cover individuals originating from Middle-Eastern, North-African, and some West-Asian countries. Possible disparities are tested using Pearson correlations between 
the proportion of convicted women and non-Western immigrants and time. The output, Pearson's $r$, indicates the strength and direction of the correlation. A positive value indicates the proportion of convicted individuals from the group of interest increases over time.

\section{Results}

Here, I first describe cannabis prevalence rates, as a proxy for problem pressure. Next, I examine the changes in drug control policies as stated in the governmental white papers, action plans, and legal amendments. Important changes are used to hypothesise break and transition periods that are used in the following analyses. Third, I describe the trend in control enforcement intensity measured as the annual number of reported drug law offences and compare with the overall trends in offences at the misdemeanour and penal code levels. Fourth, to examine temporal aspects of implementation, the regional variations in reported offences over time are presented by police districts. Next, seasonal variations in offences are presented to elaborate on the opportunity perspective in enforcement. To conclude, I examine the association between the number of offences and the gender and ethnic composition of convictions.

\section{Problem Pressure and Policy Changes}

Cannabis use increased in Denmark in the 1990s but appears to have stabilised since. Danish drug use surveys suggest that from 1994 to 2000, monthly cannabis prevalence in the age group 16-44 years increased from 2.4 to $4.3 \%$ and annual prevalence from 7.4 to $9.8 \%$, corresponding to relative increases of 79 and 32\% (National Board of Health 2010). This trend was common in the Western world during the 1990s (Feilding et al. 2008) and formed the basis for the theory of 'normalisation' (Parker 2005), which describes the widespread acceptance of recreational use among young people, high accessibility of illicit drugs, and cultural adaptation. Among 15-16-year-olds, there has been a substantial decline from 1999 to today (ESPAD 2015), but for older age groups, prevalence levels appear to have plateaued around the 2000 level (EMCDDA 2017). The absolute number of persons in the age group 16-34 years has declined slightly between 2000 and 2017 (Denmark's Statistics Table BEF5).

In the 1990s, policymakers were mostly concerned with drugs like heroin and cocaine while legal amendments in the 2000s have emphasised cannabis offences. The policy document that influenced the early part of the period is the governmental white paper (1994) on drug abuse, drug-related deaths, and treatment options. The section that addresses control issues focuses on the policing of open-air heroin sales (Laursen and Jepsen 2002). The legal amendments that followed increased the sanction for possession of small amounts of heroin and cocaine, aimed at street-level retail sellers (Act no. 1052 of December 5, 1996, Deportation of foreign nationals for drug offences, Act no. 1054 of December 11, 1996, Sanction increases for repeat sale of hard drugs) (Houborg 2010).

Nine years later, the government published the action plan Fight against Drugs (2003). In this document, the focus moves towards cannabis and the organised criminal groups believed to be responsible for much of the trade. The document explains how criminals exploit the lenient policy by "making a fool of society" (Government 2003, p. 12) and argues for several sanction increases. Three legal amendments that increased penalties followed shortly: provisions that enable police to investigate organised crime (Act no. 436 of June 10. 2003, Fighting 
outlaw biker crime and other organised crime); sanction increases for drug distribution (Act no 218 of March 31, 2004, Penalties and provisions on penalty setting, etc.); and fines for possessing cannabis for personal use (Act no. 445 of June 9, 2004, Stricter effort against drugs, etc.) (Retsinformation.dk n.d.). In contrast, the second action plan from 2010 contains only minor suggestions for legal amendments. The focus here is on maintaining or increasing the intensity of drug law enforcement with references to the longer-term harm-reducing effects of deterring potential new users (Government 2010).

From 1996 to 2004, a series of qualitative adjustments to the legal framework increased sanctions and referenced deterring inexperienced users and fighting streetlevel heroin sales (Houborg 2010). Houborg et al. (2016) note that the amendment from 2004 meant that police would issue fines as default for possession offences instead of the former practice of issuing formal warnings as sanctions. In 2003 and 2004, the large street-level retail market for cannabis in Christiania made the traditionally lenient policy appear incoherent. The increase in the cannabis trade and the harm to society from organised sales loomed larger than saving users from criminal sanctions. The action plan from 2003 called for more enforcement towards cannabis and was followed by a crackdown on Christiania's market in 2004 (Balvig 2005; Moeller 2018a, b, 2019), perhaps signalling quantitative adjustments to implementation intensity.

There is limited research on control policy implementation in Denmark after 2010, but Houborg et al. (2016) found that the policy intention of increasing enforcement towards minor drug law offences was consistently implemented at the street level in Copenhagen. When taken together, these policy documents and legal amendments suggest that policymakers have responded to what they perceive as changes in underlying problem pressure. They have acted in ways that seek to achieve coherence by adapting the legal framework regarding criminal sanctions. In the next section, I describe how this implementation can be seen in the quantitative data on reported drug law offences. I examine how the action plans were followed by changes in the intensity of drug law enforcement.

\section{Reported Offences over Time}

The most notable overall trends in offending in Denmark are the reduction in the number of penal code offences and the increase in special law offences. Penal code offences decreased $26 \%$ from 528,488 in 1996 to 393,437 in 2017. In the same period, the number of all special law offences increased from 67,702 to 126,833 , corresponding to an $87 \%$ rise. Particularly, the period after 2011 has many special law offences. The difference in the mean annual number of reported incidents for 1996-2010 $(M=15,007$; $S D=2447)$ compared to the mean for 2011$2017(M=22,749 ; S D=1995)$ is over 50\% $(t(20)=-7.29 ; p<.001)$. The number of offences in the three periods 1996-2003, 2004-2010, and 2011-2017 are different because of the marked increase of almost $50 \%$ in the third period; $X^{2}(2)=21.97 ; p<.001$.

From 1996 to 2017, there was an increase in the number of drug-related offences after both penal code Section 191 and the Law on Euphoria-Inducing Substances (LES). Focusing on the penal code offences, there were 921 reported cases of drug sales and trafficking after section 191 in 1996. This rose modestly to 978 in 2017, corresponding to a relative increase of $6 \%$. The annual average for the period was 831 reported offences $(S D=137)$. This relative stability in total serious drug offences goes against the overall decline in penal code offences. However, it should be noted that 1996 was an unusual year with a high number of cases. 
The trend in misdemeanour drug offences has been different. From 1996 to 2017, there has been an average of 17,471 reported crimes after LES per year $(S D=4284)$. This mean covers an increase from 13,986 reported offences in 1996 to 25,554 in 2017, corresponding to an $83 \%$ increase. This trend broadly follows the increase in the special laws (subtracted LES) and the share of special law offences that are drug-related has been consistent at around $22 \%$ since 1996. However, from the first to the second period, the average number of offences increases by $34 \%$ from 12,799 to 17,190 . From the second to the third period, the relative increase continues with another $29 \%$ (Fig. 1). The number of LES offences is not evenly distributed across the three periods; $X^{2}(2)=35.48 ; p<.001$.

On closer inspection of the LES offences, there are 3 years, in particular, with substantial increases. From 2003 to 2004, the number of reported offences increases by $16 \%$ and from 2004 to 2005 by an additional 19\%. From 2010 to 2011, the increase was $10 \%$. The increase from 2003 to 2005 is attributable to the declared policy change towards the open cannabis market in Copenhagen's Christiania district, which was communicated in the government's action plan Fight against Drugs I from 2003. Cannabis had been sold quite openly in this area for 30 years with acceptance from politicians, but when cannabis prevalence grew, sales appeared increasingly organised and eventually, a crackdown was implemented in 2004 (Moeller 2018a). The following action plan from 2010 Fight against Drugs II stated that enforcement intensity against possession offences should continue, but no longer contained references to the specific cannabis market in Copenhagen.

In summary, when assessing the qualitative changes in combination with the trend in reported offences over time, I propose the following policy periods: 1996-2003 was primarily qualitative changes to the legal framework. 2004-2010 was a quantitative increase in enforcement intensity, mostly from the crackdown on cannabis retail sales in Copenhagen. The period from 2011 to 2017 appears to have continued the increase in enforcement intensity, with a

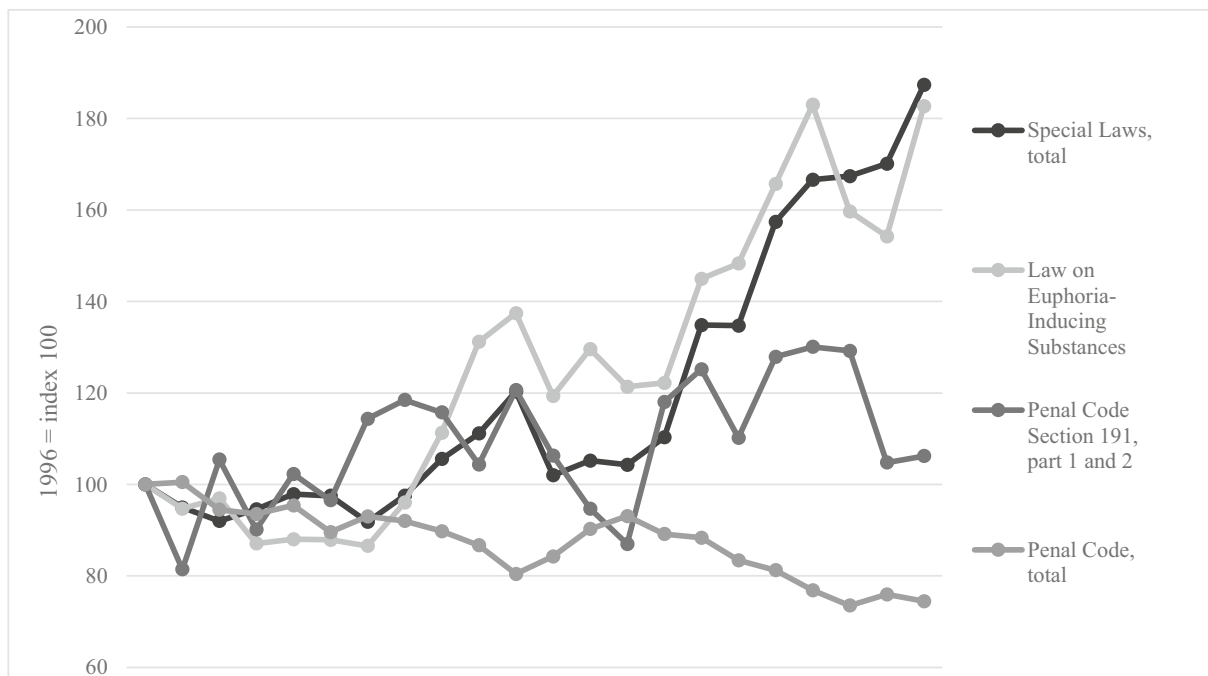

60

Fig. 1 Indexed reported offences after the penal code and special laws, subtracted drug law offences, and reported offences after Law of euphoria-inducing substances offences, Penal code section 191 (Kilde: Denmark's Statistics, Table: STRAF20) 
stable level of serious drug offences and a marked increase in reported drug law misdemeanours after LES. However, the policy documents no longer focus on the issues specific to Copenhagen. In the following section, I examine the notion that after 2011, police districts outside of Copenhagen drive the overall increase in enforcement intensity.

\section{Regional Variations in Reported LES Offences, 2007-2017}

Over the period, all twelve police districts have seen an increase in reported LES offences. In absolute numbers, the biggest annual change in reported offences is in Copenhagen. After Copenhagen, North Jutland police district and Mid- and West Sealand police have seen the largest annual changes in reported offences. Measured as offences per 1000 citizens, Copenhagen has over twice as many as East Jutland does, with 9.75 against 3.62. Note that the range of reported offences per 1000 citizens is much higher in Copenhagen at 7.89, compared with the remaining police districts. Table 1 below shows the mean enforcement intensity for the period relative to population and the slope of the linear trend line for each district.

In relative numbers, Copenhagen has seen the smallest increase with only 5.5\%. The Midand West Sealand Police districts have registered the largest increases of 127 and $122 \%$, respectively. Three other police districts have seen increases of over $50 \%$ during this time, and the average for Denmark is a $42 \%$ increase. Especially, from 2010 onwards, it can be seen that police districts outside of Copenhagen register large increases, lending support to the hypothesis of geographic dispersion of the more intensive policing of drugs. Figure 2 below shows the indexed trend for seven selected police districts, indexed in 2007.

\section{Seasonal Variation}

In column three of Table 1, the range in the number of offences per 1000 citizens for the period is three times as high in Copenhagen compared with the average for the remaining police districts. Some of the larger cities have open drug markets but in the rest of the country, drug distribution largely takes place indoors (Moeller 2018a, b). A possible explanation for this variation is that public drug use near open-air markets provides the police with opportunities to administer fines (Cohen and Felson 1979). Following the argument that public drug use is an opportunity for increasing enforcement intensity, we would, therefore, expect to see fewer reported misdemeanour drug offences in winter compared with summer.

Table 1 Reported LES offences by police districts, 2007-2017

\begin{tabular}{llllll}
\hline Police district & $\begin{array}{l}\text { Population, } \\
\text { average for } \\
\text { period }\end{array}$ & $\begin{array}{l}\text { Offences (SD) } \\
\text { per 1000 popu- } \\
\text { lation }\end{array}$ & $\begin{array}{l}\text { Range for } \\
\text { offences per 1000 } \\
\text { population }\end{array}$ & $\begin{array}{l}\text { Annual change in } \\
\text { number of } \\
\text { offences }\end{array}$ & $\begin{array}{l}\text { Percent } \\
\text { change } \\
2007-2017\end{array}$ \\
\hline Copenhagen & 709,539 & $9.75(1.12)$ & 7.87 & 235.5 & 5.5 \\
West Copenhagen & 397,236 & $3.39(0.86)$ & 2.48 & 93.5 & 51.8 \\
North Sealand & 576,029 & $1.71(0.27)$ & 1.29 & 31.4 & 32.4 \\
Mid- and West Sealand & 444,787 & $2.81(0.94)$ & 1.55 & 99.6 & 127.4 \\
Funen & 486,866 & $2.70(0.37)$ & 2.23 & 41.3 & 56.5 \\
South Jutland & 441,975 & $2.72(0.36)$ & 2.27 & 31.1 & 51.3 \\
East Jutland & 564,727 & $3.62(0.35)$ & 2.86 & 47.7 & 29.6 \\
North Jutland & 515,469 & $2.00(0.84)$ & 1.79 & 125.4 & 121.7 \\
Denmark & $5,600,606$ & $3.70(0.51)$ & 3.04 & 855.5 & 42.2 \\
\hline
\end{tabular}

Source: Denmarks Statistic's, Table STRAF22 


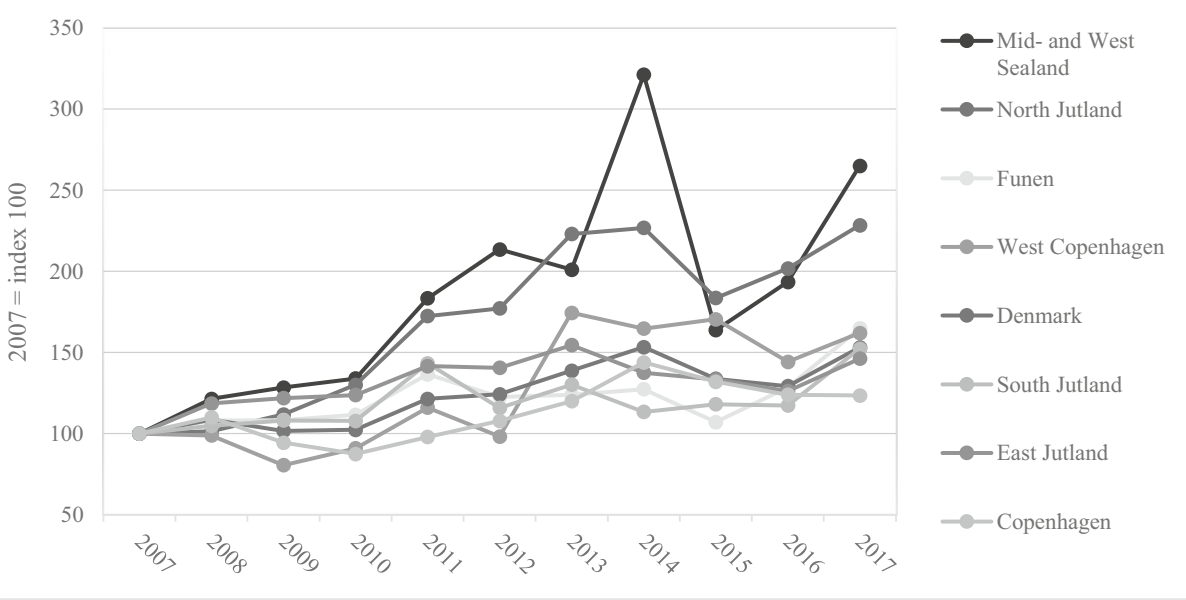

Fig. 2 Reported offences after LES by police district, index 2007. (Kilde: Denmark's Statistics, Table: STRAF22)

To analyse season variations in LES offences, I first used an ARIMA $(0,1,1)(0,1,1) 4$ model to examine variations in enforcement intensity between the four seasons of the year. With four quarters of the year and 22 years, the model had a statistically significant Ljung-Box Q statistic of 26,982 with 16 degrees of freedom at $p=.042$. This suggests the null hypothesis can be rejected as the residuals appear to be correlated. The variations between seasons are not white noise but reflect a pattern. Table 2 below shows the seasonal adjustment factors for each quarter of the year in the three periods and the period of analysis as a whole. These seasonal factors suggest that much of the variation is accounted for by consistently high numbers of reported offences in the second quarter. Offence numbers are mostly skewed in the third period with low numbers during the first quarter and very high numbers in the second quarter.

To further probe this issue, I reduce the seasons to winter and summer. Again, the period is grouped into three intervals: 1996-2003, 2004-2010, and 2011-2017. In the first period, 1996-2003, there are actually more offences during the winter and the difference (274) between winter $(M=6537 ; S D=220)$ and summer $(M=6263 ; S D=238)$ is significant; $t$ $(30)=3.39 ; p=.002$. The number of offences increases from 2004 to 2010 but the difference between winter and summer decreases. The difference (13) between winter $(M=8602 ; S D=$ $347)$ and summer $(M=8589 ; S D=377)$ is not significant; $t(26)=.09 ; p=.93$.

The most notable difference is seen in the final period of 2011-2017. There are markedly more offences compared with the previous two periods, and it is the only period with more offences during summer. The difference is substantial (905) and the $t$ test shows that during winter $(M=10,653 ; S D=450)$, there are significantly fewer offences compared with summer $(M=11,558 ; S D=784) ; t(26)=-3.75 ; p<.001$. For LES offences, there appears to be a

Table 2 LES season adjustment factors, 1996-2017

\begin{tabular}{lllll}
\hline Seasonal factor & $1996-2003$ & $2004-2010$ & 2011-2017 & 1996-2017 \\
\hline First quarter & 68.8 & -7.8 & -476.2 & -90.7 \\
Second quarter & 57.1 & 144.7 & 431.6 & 183.8 \\
Third quarter & -169.1 & -90.3 & 55.3 & -83.7 \\
Fourth quarter & 43.3 & -46.6 & -10.8 & -9.4 \\
\hline
\end{tabular}


pattern where the periods with the most offences also have larger seasonal variations. As the number of offences increases over time, the balance between the seasonal rates changes in favour of more offences reported in summer. This pattern does not appear to hold for misdemeanour offences in general. Total special law offences, subtracting LES offences, did not display a systematic seasonal pattern. In the best fitting ARIMA $(1,0,0)(1,1,0) 4$ model with 16 degrees of freedom, the Ljung-Box Q statistic of 14,449 was insignificant at $p=.57$.

The seasonal variation for all special law offences in the first period of 1996-2003 is small (247) and is not statistically significant between winter $(M=25,522 ; S D=834)$ and summer $(M=25,275 ; S D=653) ; t(30)=0.93 ; p=.36$. In the following period, 2004-2010, the difference in the number of reported offences (112) during winter $(M=26,562 ; S D=1290)$ and summer $(M=26,450 ; S D=928)$ is even smaller; $t(26)=0.26 ; p=.79$, but there is more variation than in the first period. In the third period, there are more offences in winter. This difference in the number of offences (1959) in winter $(M=39,042 ; S D=2912)$ and summer $(M=37,083 ; S D=2362)$ is not significant in a $t$ test; $t(26)=1.95 ; p=.06$, but the dispersion is bigger than in the other two periods.

These variations between quarters and winter-summer suggest that drug control implementation is not dispersed evenly over a year. The warmer months, and particularly, the spring months, have higher numbers of reported offences during the last time period under examination. In an environmental criminology perspective, these months offer more opportunities for police to issue fines because there is more drug use in public. This relates to the question of police discretion. Street-level enforcement tends to result in sanction disparities. In the final two sections of the paper, I examine gender and ethnic disparities in drug convictions.

\section{Gender Disparity in Convictions, 1996-2017}

Existing research on street-level drug policing finds young men to be overrepresented among convicted individuals. In an opportunity perspective, this may be explained by men's higher frequency of use and use in public (Nguyen and Reuter 2012). In this section, I examine overall trends in criminal sanctioning and gender distribution and focus on the specifics of drug-related criminal sanctioning and gender disparities.

Total penal code convictions have declined since 1996 and convictions against men are down 29\% in 2017 compared with 1996. The relative decline has been the biggest for women, with $35 \%$ fewer convictions over the period. In relation to all penal code convictions, this corresponds to a small decline in women's share of the total, from 19.2 to $17.9 \%$, but the correlation between the share of all convicted individuals who are women and time is not significant $(r=.19 ; p=.20$ ). The proportion of women among the convicted for all penal code violations, subtracting Section 191 offences, and the proportion of women among convicted individuals after Section 191 are not significantly different either $(r=-.26 ; p=.12)$. For total special law convictions, subtracting LES, there is a large increase in the number of convictions against women, of $222 \%$ from 1996 to 2017. This amounts to an increase from $10 \%$ of all convictions to $12.3 \%$. Both the correlation with time $(r=.60 ; p=.002)$ and women's share of total special law convictions $(r=.67 ; p<.001)$ are statistically significant, but the strength of the association is moderate. The number of convictions against men has increased by $154 \%$ over the same period and this corresponds to a minor relative decline in their share of the total, from 90 to $87.7 \%$.

For all drug convictions combined, Section 191 of the penal code and LES, women's share has decreased to $10 \%$ in 2017 , down from $15 \%$ in 1996 . The association between women's 
share of convictions and time is strongly negatively correlated $(r=-.78 ; p<.001)$ and more modestly correlated with the total number of convictions $(r=-.691, p<.001)$. The overall pattern appears to be that when the total number of convictions increased, women's share decreased. Specifically, for the sale of drugs after the penal code's Section 191, Part 1, there has been a marked increase in the number of convictions against men of 92\%, from 1996 to 2017 while there are $21 \%$ more convictions against women. For Section 191, Part 1, convictions, women's share of the total is strongly negatively correlated with time $(r=-.76$; $p<.001)$ and moderately negatively correlated with the share of total convictions $(r=-.61$; $p<.001)$. The pattern of more convictions entailing a lower share of women also holds when focusing on serious drug sale offences after the penal code's Section 191.

The most notable trend in gender distribution and drug offences is in relation to LES. There are 55\% more convictions against men in 2017 compared with 1996 while the number of convictions against women has been stable around 920 per year $(S D=175)$. Women's share of LES convictions are strongly negatively correlated with time $(r=-.77 ; p<.001)$ and less strongly correlated with the total number of convictions $(r=-.68 ; p<.001)$. The largest relative increase in convictions against men for LES occurred in 2005, in extension of the intensified enforcement against the cannabis market on Pusher Street in Christiania (Moeller 2018a). The average number of annual convictions until 2004 was 6.874 (SD=599), compared with 11,978 $(S D=1654)$ from 2005 onwards, $t(20)=-8.81 ; p<.001$. There is also an increase in convictions against women during this period but it is not as substantial. Until 2004, the annual mean was $803(S D=135)$, compared with $1001(S D=151)$ after; $t(20)=-$ $3.15 ; p=.003$. The overall pattern of increasing gender disparity with the increasing number of convictions over time also holds for LES convictions.

\section{Ethnic Disparity in Convictions, 2000-2017}

Criminological research on policing finds that more intensive policing of minor offences typically implies a larger share of ethnic minorities among the convicted (Golub et al. 2007; Medina 2014). Moeller (2012) found the share of convictions after LES that were against immigrants from non-Western countries and their descendants correlated with both time and the total number of convictions from 2000 to 2008. More convictions were associated with a larger share of the convicted having a non-Western origin. This pattern appears to have continued since. The share of convictions that are against immigrants from non-Western countries and the descendants of immigrants from non-Western countries increased from 10 to $21 \%$ from 2000 to 2017 . This increase is strongly correlated with time $(r=.86 ; p<.001)$ and weakly correlated with the total number of convictions after LES $(r=.23 ; p<.001)$.

Seen in relation to the period, before and after the crackdown on Pusher Street in 2004, the same pattern appears. The number of convictions after LES against immigrants from nonWestern countries from 2000 to $2004(M=634, S D=131)$ is markedly lower than the period from 2005 to $2017(M=1145, S D=91)$ in absolute numbers and the difference is significant; $t$ $(14)=-8.16 ; p<.001$. Correspondingly, for descendants of immigrants from non-Western countries, even though the numbers are smaller, the number of convictions from 2000 to 2004 $(M=157, S D=49)$ was lower compared with 2005-2017 $(M=642, S D=241) ; t(14)=-3.38$; $p=.002$. When the number of convictions after LES increased following the 2004 crackdown, the share of convictions against immigrants and descendants from non-Western countries increased. Higher law enforcement intensity against minor drug offences appears to increase the ethnic disparity of convictions. 


\section{Discussion and Conclusion}

In this article, I presented measures of drug seizure numbers and reported offences in Denmark over a 22-year period to give a better representation of drug control intensity compared with the law on the books. This study was aimed at describing patterns and correlates of policy implementation from an opportunity theory perspective. Most research on these issues depart from law on the books approaches, but the relationship between the law on the books and penal practice is far from uncomplicated. I applied seizure numbers and reported offences as the central measures. This measure emphasises the risks experienced by users and sellers of illicit drugs in a way that is suitable for future comparative analysis. This endeavour has both theoretical and policy implications, particularly at the present time when drug policies are changing internationally and the utility of the control aspect is contested. Many European countries are experimenting with more lenient approaches to drug law misdemeanours, but the trend in Denmark has been opposite, moving from a lenient starting point towards a more repressive approach.

There are contrasting theories about what motivates the increase in drug law enforcement towards misdemeanours. Some would see this as an example of "defining up" deviance as a result of political needs (Mooney and Young 2006), at a time when the overall crime rate is declining, when measured as the number of reported offences. In contrast to this perception, a recent study suggested that the problem pressure from crime in Denmark has, in fact, increased in recent years, when ascribing more weight to severe offences (Andersen and MuellerJohnson 2018). In this article, I have contextualised policy documents with drug use statistics and argued that the aggregate problem pressure may have motivated a change in the overall policy objectives, away from harm reduction and towards use reduction.

In this perspective, the increase in reported drug law offences is a response to a growing problem from more widespread drug use where policymakers strive for coherence between problems and responses (Adam and Raschzok 2014).

I first examined whether enforcement levels followed a pattern of phases of qualitative and quantitative adjustments. My findings indicated that the overall temporal trend in drug offences followed a pattern of phases, but when seen over the entire period, the general trend broadly followed overall crime trends. The exception was the decline in overall penal code offences. Where drug offences after the penal code Section 191 have been stable throughout the period from 1996 to 2017, the numbers of all penal code offences have declined $26 \%$ while serious drug law offences have remained stable. This may speak to the proactivity required from police in investigating drug offences. Serious drug crimes have remained a focus for police, during a period in which reported penal code offences have gone down.

To further probe the issues of police proactivity and opportunity, I examined geographic and seasonal variations. Danish police are not required to act on all offending they observe and this margin of discretion may influence fluctuations in reported offences over a year as seasonal variations reflect outdoor drug activity. While there did not appear to be a systematic pattern in the quarterly variation in reported offences for misdemeanours in general, there did appear to be a pattern for LES where there are more reported offences in the spring quarter. The period from 2011 to 2017 had the highest level of enforcement intensity and was also the only period with more reported offences during the six summer months, as compared with the six winter months. This may suggest that during years in which the police are proactive against drug law offending in public, they tend to be more successful during spring months. 
Lastly, I examined if the proposition that gender and ethnic disparities in minor drug offences increase when police intensify enforcement. My results are in accordance with prior research on the subject, as I found that when enforcement intensity increased, the data suggest that disparities also increase. Where police discretion plays a large role, individual-level characteristics may exert influence. A substantial criminological literature has examined this issue, and in Denmark, Houborg et al. (2016) also found that officers' suspicion can arise from certain individual characteristics. However, in this article, I have focused on the opportunity perspective where the differences between social groups may rather reflect risky behaviour by users' outdoor drug activity. Alternatively, the disparity between the genders could be explained by the chivalry thesis whereby police treat women more leniently than men (Nguyen and Reuter 2012). The difference in the ethnic composition may follow from a higher police presence in areas with dense populations of ethnic minorities (Blumstein 1995) or higher use rates (Jayakody et al. 2006), but there is no data from Denmark at present to examine this proposition.

The findings speak to the theoretical propositions of policy coherence. Danish cannabis policy changed in temporal succession of changes in use rates. My analyses suggest this increase in enforcement intensity, particularly since 2004, may have been motivated by the need for policy coherence. The combination of increased cannabis prevalence and easy availability in the 1990 s could not be reconciled with a lenient control of cannabis. To policymakers, these trends amounted to increased problem pressure and the aim of Danish control policy switched from protecting users from harm to deterring use and protecting society from the criminals that profit from distributing illicit drugs (MacCoun and Reuter 2001). In practice, this meant increasing deterrence by issuing criminal sanctions, making penalties more certain. Prior research on drug control policy in Denmark has largely focused on the increases in sanction severity and failed to account for the changes in underlying problem pressure. When considering changes in use rates and the market that served new users, the policy of increasing sanctions and enforcement appear as defensive responses more than ideologically driven "repressive" policies.

Lastly, summarising the findings on policy coherence, I found that the pattern of transition and break periods that have been hypothesised using qualitative data (Laursen and Jepsen 2002) was also discernible in the quantitative data. The period from the first government white paper in 1994 to the series of legal amendments that ended in 2003 resembled a break period as the level of reported drug law offences was stable. Towards the latter part of the period, a series of qualitative changes were introduced that focus on deterring sellers and buyers by increasing sanctions (Balvig 2005; Houborg 2010).

The following period from 2004 and after sees only minor adjustments to the legal framework but a marked increase in enforcement intensity that follows explicit deterrent aims set forth in the two government action plans, Fight against Drugs I and II, from 2003 and 2010. The period after 2003 is a transition period with quantitative adjustments in policy implementation (Laursen and Jepsen 2002) and this continued and further increased in 2011, albeit not as much. My analysis indicates regions outside of Copenhagen are driving the trend after 2011. Copenhagen still has the highest offence rate to the number of citizens, but the rest of the country has been catching up for the past 10 years. Seen sequentially, this resembles the path of maintaining a coherent policy towards illicit drugs, adjusting the legal framework and enforcement intensity in steps to counter the incoherence that follows from periods with increasing problem pressure. 
The implications for further research concern the methodological approach of applying deterrence theory to the available data and focus on the number of seizures and offences, rather than sanction severity (Ødegård 1998). This recommendation comes when drug control policies are being debated vigorously following international changes to cannabis policy. When evaluating the outcomes of national-level changes to policy, the input measures should include enforcement intensity relative to population and use rates. Policymakers should note the mounting evidence that increased enforcement intensity correlates with higher ethnic disparity among the convicted. In conclusion, it is worth noting the two previous transition periods, with quantitative changes in Laursen and Jepsen's (2002) analysis, were short, as they only lasted 6 years from 1973 to 1978 and 9 years from 1985 to 1993 . In this context, the current period of high enforcement intensity is comparably long, as it started in 2004.

Funding Information Open access funding provided by Malmö University.

Open Access This article is licensed under a Creative Commons Attribution 4.0 International License, which permits use, sharing, adaptation, distribution and reproduction in any medium or format, as long as you give appropriate credit to the original author(s) and the source, provide a link to the Creative Commons licence, and indicate if changes were made. The images or other third party material in this article are included in the article's Creative Commons licence, unless indicated otherwise in a credit line to the material. If material is not included in the article's Creative Commons licence and your intended use is not permitted by statutory regulation or exceeds the permitted use, you will need to obtain permission directly from the copyright holder. To view a copy of this licence, visit http://creativecommons.org/licenses/by/4.0/.

\section{References}

[Attorney General] Rigsadvokaten. (2006). [Amounts delineating penal code section 191 and Law on euphoriainducing substances] Afgrænsningen mellem $\S 191$ og lov om euforiserende stoffer. Retrieved from: https:/vidensbasen.anklagemyndigheden.dk/h/6dfa19d8-18cc-47d6-b4c4-3bd07bc15ec0/VB/3d612e4f2e19-409d-918f-c6605e887612\#ID0EYMAE

[Government] Regeringen. (2003). Regeringens handlingsplan: Kampen mod narko [Government action planThe Fight against Drugs]. København: Statens Informationstjeneste.

[Government] Regeringen. (2010). Kampen mod narko II-handlingsplan mod narkotikamisbrug [The fight against drugs II - action plan against drug abuse]. København: Statens Informationstjeneste.

[Ministry of Justice, Social Ministry, and Health Ministry] Justitsministeriet, Socialministeriet og Sundhedsministeriet (1994). Bekæmpelse af narkotikamisbruget (Fighting drug abuse]. Governmental white paper). København: Statens Informationstjeneste.

[National Board of Health] Sundhedsstyrelsen. (2010). Narkotikasituationen i Danmark [Drug Situation in Denmark]. København: Sundhedsstyrelsen.

Adam, C., \& Raschzok, A. (2014). Explaining trends in addictive behaviour policy-the role of policy coherence. International Journal of Drug Policy, 25(3), 494-501. https://doi.org/10.1016/j. drugpo.2014.02.013.

Andersen, H. A., \& Mueller-Johnson, K. (2018). The Danish Crime Harm Index: how it works and why it matters. Cambridge Journal of Evidence-Based Policing, 2(1-2), 52-69. https://oi.org/10.1007/s41887-018-0021-7.

Babor, T., Caulkins, J., Edwards, G., Fischer, B., Foxcroft, D., Humphreys, K., Obot, I., Rehm, J., Reuter, P., Room, R., Rossow, I., \& Strang, J. (2010). Drug policy and the public good. Oxford: Oxford University Press.

Balvig, F. (2005). When law and order returned to Denmark. Journal of Scandinavian Studies in Criminology and Crime Prevention, 5(2), 167-187. https://doi.org/10.1080/14043850410010711.

Blumstein, A. (1995). Youth violence, guns, and the illicit-drug industry. Journal of Criminal Law and Criminology, 86, 10.

Box, G. E. P., \& Jenkins, G. (1970). Time series analysis - forecasting and control. Holden-Day, San Francisco, CA, 1970 .

Bruun, K., \& Rosenqvist, P. (1980). Alcohol and drug control policies in the Nordic countries. Journal of Drug Issues, 10(4), 421-432. https://doi.org/10.1177/002204268001000403. 
Burris, S. (2017). Theory and methods in comparative drug and alcohol policy research: response to a review of the literature. International Journal of Drug Policy, 41, 126-131. https://doi.org/10.1016/j. drugpo.2016.11.011.

Bushway, S., \& Reuter, P. (2008). Economists' contribution to the study of crime and the criminal justice system. Crime and Justice, 37(1), 389-451. https://doi.org/10.1086/524283

Caulkins, J., \& Reuter, P. (1997). Setting goals for drug policy: harm reduction or use reduction? Addiction, 92(9), 1143-1159. https://doi.org/10.1111/j.1360-0443.1997.tb03673.x.

Cohen, L. E., \& Felson, M. (1979). Social change and crime rate trends: a routine activity approach. American Sociological Review, 44(4), 588-608. https://doi.org/10.2307/2094589.

Cornish, D. B., \& Clarke, R. V. (Eds.). (1986). The reasoning criminal. New York: Springer.

EMCDDA (European Monitoring Center for Drugs and Drug Addiction). (2017). European drug report 2017 trends and developments. EMCDDA: Lisbon.

ESPAD. (2015). The European school survey project on alcohol and other drugs. EMCDDA: Lisbon.

Feilding, A., Room, R., Fischer, B., Hall, W., Lenton, S., \& Reuter, P. (2008). Cannabis policy: moving beyond stalemate - the global cannabis commission report. Oxford: The Beckley Foundation.

Golub, A., Johnson, B. D., \& Dunlap, E. (2007). The race/ethnicity disparity in misdemeanor marijuana arrests in New York City. Criminology \& Public Policy, 6(1), 131-164. https://doi.org/10.1111/j.1745-9133.2007.00426.x.

Harcourt, B. E., \& Ludwig, J. (2007). Reefer madness: Broken windows policing and misdemeanor marijuana arrests in New York City, 1989-2000. Criminology \& Public Policy, 6(1), 165-181.

Houborg, E. (2010). Control and welfare in Danish drug policy. Journal of Drug Issues, 40(4), $783-804$. https://doi.org/10.1177/002204261004000402.

Houborg, E., Kammersgaard, T., \& Pedersen, M. (2016). Drug policing in four Danish police districts. Police Practice and Research, 17(4), 329-340. https://doi.org/10.1080/15614263.2016.1175173.

Jayakody, A. A., Viner, R. M., Haines, M. M., Bhui, K. S., Head, J. A., Taylor, S. J. C., Booy, R., Klineberg, E., Clark, C., \& Stansfeld, S. A. (2006). Illicit and traditional drug use among ethnic minority adolescents in East London. Public Health, 120(4), 329-338. https://doi.org/10.1016/j.puhe.2005.10.009.

Laursen, L., \& Jepsen, J. (2002). Danish drug policy - an ambivalent balance between repression and welfare. The Annals of the American Academy of Political and Social Science, 582(1), 20-36. https://doi.org/10.1177 /000271620258200102.

MacCoun, R. J., \& Reuter, P. (2001). Drug war heresies: learning from other vices, times, and places. New York: Cambridge University Press.

May, T., \& Hough, M. (2001). Illegal dealings: the impact of low-level police enforcement on drug markets. European Journal on Criminal Policy and Research, 9(2), 137-162. https://doi. org/10.1023/A:1011201112490.

Medina, A. J. J. (2014). Police-initiated contacts: young people, ethnicity, and the 'usual suspects'. Policing and Society, 24(2), 208-223. https://doi.org/10.1080/10439463.2013.784301.

Moeller, K. (2010). Policy displacement and disparate sanctioning from policing cannabis in Denmark. Journal of Scandinavian Studies in Criminology and Crime Prevention, 11(2), 135-150. https://doi.org/10.1080 /14043858.2010.502014.

Moeller, K. (2012). Estimating drug policy expenditures: direct costs of policing cannabis markets in Copenhagen 2000-2009. Drugs: Education, Prevention and Policy, 19(5), 379-386. https://doi. org/10.3109/09687637.2012.658888.

Moeller, K. (2018a). Video-recorded retail cannabis trades in a low-risk marketplace: trade value and temporal patterns. Journal of Research in Crime and Delinquency, 55(1), 103-124. https://doi.org/10.1177 /0022427817701256.

Moeller, K. (2018b). Drug market criminology: combining economic and criminological research on illicit drug markets. International Criminal Justice Review, 28(3), 191-205. https://doi.org/10.1177 $/ 1057567717746215$.

Moeller, K. (2019). Sisters are never alike? Drug control intensity in the Nordic countries. International Journal of Drug Policy, 73, 141-145. https://doi.org/10.1016/j.drugpo.2019.06.004.

Mooney, J., \& Young, J. (2006). The decline in crime and the rise of anti-social behaviour. Probation Journal, 53(4), 397-407. https://doi.org/10.1177/0264550506069364.

Mounteney, J., Griffiths, P., Sedefov, R., Noor, A., Vicente, J. and Simon, R. (2016). The drug situation in Europe: an overview of data available on illicit drugs and new psychoactive substances from European monitoring in 2015. Addiction, 111(1), 34-48. https://doi.org/10.1111/add.13056.

Nagin, D. S., \& Paternoster, R. (1991). The preventive effects of the perceived risk of arrest: testing an expanded conception of deterrence. Criminology, 29(4), 561-587. https://doi.org/10.1111/j.1745-9125.1991.tb01080.x.

Nguyen, H., \& Reuter, P. (2012). How risky is marijuana possession? Considering the role of age, race, and gender. Crime \& Delinquency, 58(6), 879-910. https://doi.org/10.1177/0011128712461122. 
Ødegård, E. (1998). Comparative research in the drug field. European Journal on Criminal Policy and Research, 6(3), 357-367. https://doi.org/10.1023/A:1008695313417.

Parker, H. (2005). Normalization as a barometer: recreational drug use and the consumption of leisure by younger Britons. Addiction Research and Theory, 13(3), 205-215. https://doi.org/10.1080/16066350500053703.

Pedersen, W., \& Skardhamar, T. (2010). Cannabis and crime: findings from a longitudinal study. Addiction, 105(1), 109-118. https://doi.org/10.1111/j.1360-0443.2009.02719.x .

Ratcliffe, J. H. (2006). A temporal constraint theory to explain opportunity based spatial offending patterns. Journal of Research in Crime and Delinquency, 43(3), 261-291. https://doi.org/10.1177 /0022427806286566.

Retsinformation.dk. Retrieved from www.retsinformation.dk/Forms/R0200.aspx

Reuter, P. (2006). What drug policies cost. Estimating government drug policy expenditures. Addiction, 101(3), 315-322. https://doi.org/10.1111/j.1360-0443.2005.01336.x.

Ritter, A., Livingston, M., Chalmers, J., Berends, L., \& Reuter, P. (2016). Comparative policy analysis for alcohol and drugs: current state of the field. International Journal of Drug Policy, 31, 39-50. https://doi.org/10.1016/j. drugpo.2016.02.004.

Rogeberg, O. (2018). Prohibition, regulation or laissez faire: the policy trade-offs of cannabis policy. International Journal of Drug Policy, 56, 153-161. https://doi.org/10.1016/j.drugpo.2018.03.024.

Weisburd, D., \& Green, L. (1995). Policing drug hot spots: the Jersey City drug market analysis experiment. Justice Quarterly, 12(4), 711-735. https://doi.org/10.1080/07418829500096261.

Publisher's Note Springer Nature remains neutral with regard to jurisdictional claims in published maps and institutional affiliations. 